\title{
EVALUATION OF DECONTAMINATION METHODS OF BLOOD/SALIVA IN THE BONDING OF ORTHODONTIC ACCESSORIES
}

\author{
AVALIAÇÃO DE MÉTODOS DE DESCONTAMINAÇÃO DE SANGUE/SALIVA NA \\ COLAGEM DE ACESSÓRIOS ORTODÔNTICOS
}

\section{Matheus Melo PITHON ${ }^{1}$; Rogério LACERDA-SANTOS ${ }^{2}$; Nathali Cafeseiro DEL ${ }^{\prime}$ REY $^{3}$; Vanessa BATISTA ${ }^{3}$; Bráulio Carneiro JÚNIOR ${ }^{4}$}

1. Professor, Department of Orthodontics, State University of Southwest Bahia, Jéquie, Bahia, Brazil. matheuspithon@gmail.com; 2. Professor, Department of Orthodontics, Federal University of Campina Grande, Patos, Paraíba, Brazil. lacerdaorto@ @otmail.com; 3. Student of Dentistry, Department of Orthodontics, State University of Southwest Bahia, Jéquie, Bahia, Brazil; 4. Professor, Department of Surgery, State University of Southwest Bahia, Jéquie, Bahia, Brazil.

\begin{abstract}
This study aimed to evaluate the best method for decontaminating tooth enamel contaminated with blood/saliva before bonding orthodontic accessories, since such contamination is commonly present in surgical procedures of extrusion/orthodontics. 195 bovine incisors were used. Initially their vestibular faces received prophylaxis, H3PO4 at 37\% and adhesive application. After this, the vestibular faces of all the teeth were contaminated with blood/saliva. The teeth were then randomly divided into 13 groups $(n=15)$, Group $C$ (Control - without contamination and bonded according to manufacturer's recommendations) and 12 experimental groups according to the decontamination method: Group WD- without decontamination, Group DW- washed with distilled water, Group PS- washed with physiologic solution, Group JA- jets of air, Group G- gauze, Group CW- cotton wool, Group DW+JA- distilled water + jets of air, Group DW+G- distilled water + gauze, Group DW+CW- distilled water + cotton wool, Group PS+JAphysiologic solution + jets of air, Group PS + G- physiologic solution + gauze, Group PS+CW- physiologic solution + cotton wool. After bonding the shear bond strength test was performed on all the samples at a speed of $0.5 \mathrm{~mm} / \mathrm{min}$. Data were analyzed statistically by ANOVA and Tukey's test at 5\% significance level. The results demonstrated absence of statistical differences between the Control and Groups DW+JA and PS $+\mathrm{JA}(P>0.05)$. The groups that presented the lowest bond strength values were Group WD, in which no decontamination was performed, and Group PS in which specimens were washed with physiologic solution only. The best methods of decontaminating enamel contaminated with blood/saliva were washing with distilled water or physiologic solution followed by drying with jets of air.
\end{abstract}

KEYWORDS: Dental Materials. Oral Surgical Procedures. Orthodontics. Shear Strength.

\section{INTRODUCTION}

Permanent teeth play an important role in the establishment and maintenance of the form and function of dentition, and their presence in the dental arch is fundamental for the establishment of balanced, dynamic occlusion, in addition to facial esthetics and harmony. Thus, given their importance, when confronted with an impacted permanent tooth, every effort should be made to retain the tooth and prevent it from being extracted (KOKICH; MATHEWS, 1993; KOKICH, 2004; KOKICH; CRABILL, 2006).

Trans-surgical bonding of orthodontic accessories with the purpose of making it possible to align and level partially erupted teeth requires a suitable environment in which to perform the work, as it is difficult to maintain ideal conditions for bonding the accessories (HOBSON et al., 2001; SFONDRINI et., 2004). After contamination by fluids, the tooth surface decontamination process becomes quicker than repeating the whole bonding procedure. Moreover, the repeated etching would also cause further enamel loss (BRAUCHLI at al., 2010). Thus, decontamination methods have been increasingly indicated in cases of trans-surgical bonding.

The materials most used for bonding orthodontic accessories are orthodontic composites, which demand completely dry surfaces for obtaining clinically acceptable mechanical resistance (PITHON et al., 2010). However, clinical conditions during the act of surgery do not allow ideal isolation of the bonding site, and may cause failure of composites to bond to tooth enamel (CACCIAFESTA et al., 2003; OZTOPRAK et al., 2007; SAYINSU et al., 2007). The properties of a composite may be harmed by various intraoral factors, which include a high degree of humidity inside the oral cavity, aging of the tooth, dental caries, saliva and/or blood at the bonding site (CACCIAFESTA et al., 2004ab).

At the time of bonding, the acid etching process dissolves some crystals of the enamel prism, making the surface appropriate for micromechanical retention. However, momentary contamination of 
the bond areas by blood forms an organic pellicle that diminishes enamel porosity, reducing the micro retention creation, and thus making it difficult for composites to adhere (OONSOMBAT et al., 2003; OZTOPRAK et al., 2007; SAYINSU et al., 2007; CAMPOY et al., 2010).

In an endeavor to overcome enamel contamination, water and air spray is used (BRAUCHLI at al., 2010). Some studies have reported that oral cavity fluids are resistant to washing with water, but little is known with respect to the effects of other decontamination methods on the bond strength of orthodontic accessories to enamel (CACCIAFESTA et al., 2004b; CAMPOY et al., 2010; MAIA et al., 2010). Therefore the purpose of the present study was to evaluate the effects of different methods of decontamination on the shear bond strength of orthodontic buttons, used in surgeries for applying traction to partially erupted teeth, bonded to enamel previously contaminated with blood/saliva.

\section{MATERIAL AND METHODS}

In this in vitro evaluation 195 bovine permanent mandibular incisors were used, for which the inclusion criterion was that the teeth should be intact; that is to say, without cavitation. These were duly cleaned, stored in $10 \%$ formol solution, in a glass receptacle, and kept in a refrigerator at a temperature of approximately $6^{\circ} \mathrm{C}$.

The teeth were embedded in rigid PVC rings (Tigre, Joinville, Brazil) with selfpolymerizing acrylic resin (Clássico, São Paulo, Brazil), so that only their crowns were exposed.
When they were embedded, the vestibular surfaces of these crowns were placed perpendicular to the base of the die with the aid of a $90^{\circ}$ set square made of glass, with the purpose of enabling correct mechanical testing. After polishing the resin, all the sets were stored in distilled water and again placed in the refrigerator.

The vestibular surfaces of the teeth received prophylaxis with a rubber cup (Viking, KG Sorensen, Barueri, Brazil), extra-fine pumice stone (S.S.White, Juiz de Fora, Brazil) and distilled water for 15 seconds. After this, they were washed with air spray/distilled water and dried with an oil- and humidity-free jet of air for the same length of time.

Next, all specimens received the bond protocol of $\mathrm{H} 3 \mathrm{PO} 4$ at $37 \%$ for 30 seconds (FGM, Joinvile, Brazil), washing with water and drying with jets of air for the same period, and a thin coat of adhesive (Transbond XT primer, 3M Unitek, Monrovia, USA) was applied and light polymerized for 10 seconds. Both blood and saliva were collected from the examiner (V.B.). The teeth were then contaminated with a mixture of human blood / saliva in equal proportions, with the aid of an applicator brush for 10 seconds. All groups were contaminated of same manner and randomly divided into 13 groups $(\mathrm{n}=15)$, whereas one group was control, and 12 received the contamination (Table $1)$.

In the Group C (Control) no contamination or decontamination procedure was performed, and only the manufacturer's recommendations were followed. This study was approved by the Ethics Committee on Human Research, CAAE: 10933512.5.0000.5188.

Table 1. Experimental groups divided according to contamination with blood/saliva and processes of decontamination, with washing and drying, performed during analysis.

\begin{tabular}{|c|c|c|c|c|c|c|}
\hline \multirow{3}{*}{ GROUPS } & \multirow{3}{*}{ CONTAMINATION } & \multicolumn{5}{|c|}{ DECONTAMINATION } \\
\hline & & \multicolumn{2}{|c|}{ Washing } & \multicolumn{3}{|c|}{ Drying } \\
\hline & & $\begin{array}{c}\text { Distilled } \\
\text { Water }\end{array}$ & $\begin{array}{c}\text { Physiologic } \\
\text { solution }\end{array}$ & $\begin{array}{c}\text { Jets of } \\
\text { Air }\end{array}$ & Gauze & $\begin{array}{c}\text { Cotton } \\
\text { wool }\end{array}$ \\
\hline $\mathrm{C}$ & \multirow{13}{*}{ 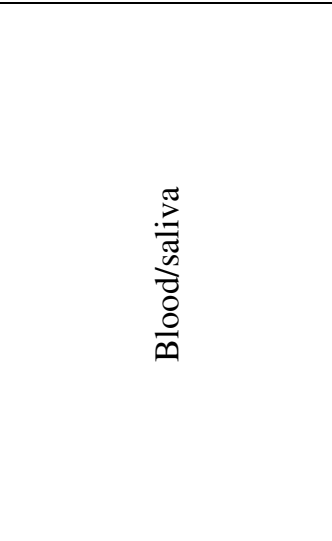 } & - & - & - & - & - \\
\hline WD & & - & - & - & - & - \\
\hline $\mathrm{DW}$ & & $\mathrm{X}$ & - & - & - & - \\
\hline PS & & - & $\mathrm{X}$ & - & - & - \\
\hline JA & & - & - & $\mathrm{X}$ & - & - \\
\hline $\mathrm{G}$ & & - & - & _ & $\mathrm{X}$ & - \\
\hline $\mathrm{CW}$ & & - & - & - & - & $\mathrm{X}$ \\
\hline $\mathrm{DW}+\mathrm{JA}$ & & $\mathrm{X}$ & - & $\mathrm{X}$ & - & - \\
\hline $\mathrm{DW}+\mathrm{G}$ & & $\mathrm{X}$ & - & - & $\mathrm{X}$ & - \\
\hline $\mathrm{DW}+\mathrm{CW}$ & & $\mathrm{X}$ & - & - & - & $\mathrm{X}$ \\
\hline $\mathrm{PS}+\mathrm{JA}$ & & - & $\mathrm{X}$ & $\mathrm{X}$ & - & - \\
\hline $\mathrm{PS}+\mathrm{G}$ & & - & $\mathrm{X}$ & _ & $\mathrm{X}$ & - \\
\hline $\mathrm{PS}+\mathrm{CW}$ & & - & $\mathrm{X}$ & - & - & $\mathrm{X}$ \\
\hline
\end{tabular}


After decontamination, orthodontic buttons were bonded with Transbond XT composite (3M Unitek, Monrovia, USA) excesses were removed, and light polymerization was performed for 40 seconds, using a LED appliance (Radii/SDI, Baywater, VIC, Australia) fixed on a rod to guarantee that the distance between the specimens remained constant, using a light intensity of 1000 mw/ $\mathrm{cm}^{2}$, regularly calibrated with a radiometer (Model 100/Demetron Research Corporation, Danbury, CT, USA).

After bonding, the test specimens were stored in artificial saliva and kept in an oven for 24 hours, at a temperature of $37^{\circ} \mathrm{C}$. The shear bond strength test was performed in a universal mechanical test machine (Filizola, São Paulo, Brazil), operating at a speed of $0.5 \mathrm{~mm} / \mathrm{min}$, through the active tip of a chisel. The shear bond strength results were obtained in $\mathrm{Kgf}$, transformed into $\mathrm{N}$ and divided by the bracket base area to provide results in $\mathrm{MPa}$.

The shear bond strength test results were submitted to the analysis of variance (ANOVA) and afterwards to the Tukey test in order to compare all the groups. Statistical significance was set at a level of 0.05 .

\section{RESULTS}

The results demonstrated that the Group C presented the highest bond strength values, and so did Groups PS+JA and DW+JA. The Groups that showed the lowest values were Groups WD, DW, PS and JA, and of these, Group WD presented statistical difference from the other groups. The other values and statistical comparisons are shown in Table 2.

Table 2. Groups, Mean and Standard Deviation of the shear bond strength values, and statistical analysis of the groups evaluated.

\begin{tabular}{llcc}
\hline \multicolumn{1}{c}{ Groups } & Mean (SD) & Stat* \\
\hline (PS+JA) & Physiologic solution + Jets of air & $27.43( \pm 27.56)$ & A \\
$(\mathrm{C})$ & Control & $26.50( \pm 15.71)$ & A \\
$($ DW+JA) & Distilled water + Jets of air & $24.80( \pm 25.05)$ & A \\
$(\mathrm{CW})$ & Cotton wool & $18.69( \pm 17.60)$ & $\mathrm{B}$ \\
$(\mathrm{PS}+\mathrm{G})$ & Physiologic solution + Gauze & $16.52( \pm 16.76)$ & $\mathrm{B}$ \\
$(\mathrm{DW}+\mathrm{CW})$ & Distilled water + Cotton wool & $15.90( \pm 19.64)$ & $\mathrm{B}$ \\
$(\mathrm{PS}+\mathrm{CW})$ & Physiologic solution + Cotton wool & $15.32( \pm 11.22)$ & $\mathrm{B}$ \\
$(\mathrm{G})$ & Gauze & $14.22( \pm 20.66)$ & $\mathrm{B}$ \\
$(\mathrm{DW}+\mathrm{G})$ & Distilled water + Gauze & $11.82( \pm 26.14)$ & $\mathrm{B}$ \\
$(\mathrm{JA})$ & Jets of air & $09.61( \pm 09.29)$ & $\mathrm{C}$ \\
$(\mathrm{DW})$ & Distilled water & $09.41( \pm 10.50)$ & $\mathrm{C}$ \\
$(\mathrm{PS})$ & Physiologic solution & $08.91( \pm 10.80)$ & $\mathrm{C}$ \\
$(\mathrm{WD})$ & Without decontamination & $04.78( \pm 02.01)$ & $\mathrm{D}$ \\
\hline
\end{tabular}

Stat* = Equal letters absence of statistically significant difference $(P>0.05) ; \mathbf{S D}=$ standard deviation.

\section{DISCUSSION}

In treatments that require and involves surgical-orthodontic procedures (YANG, 1973; FERREIRA-JUNIOR et al., 2009) the direct bonding of orthodontic screens, buttons and brackets for traction of impacted teeth has become the preferred technique (SAYINSU et al., 2007; SFONDRINI et al., 2010). However, in the bonding technique using conventional adhesive various steps are required (BRAUCHLI at al., 2010), strict control of enamel surface contamination is necessary. This is a problem that constantly faces buccomaxillofacial surgeons in the bonding orthodontic accessories (HOBSON et al., 2001;
SFONDRINI et., 2004), because in these situations, it is necessary to make an incision into tissues favoring bleeding, in addition to constant salivation in this region due to the salivary glands in the floor of the mouth.

To perform this evaluation bovine teeth were used, because previous studies have shown that human and bovine enamel are similar in their physical properties, composition and bond strength, and are reliable for use in bond studies (CACCIAFESTA et al., 2004ab; OZTOPRAK et al., 2007; SFONDRINI et al., 2010).

The orthodontic accessories used were the orthodontic button, which is the item most required by orthodontists as it is less voluminous when 
compared with brackets, with less friction than a bracket, thus diminishing inflammatory reactions at the surgical access site (SFONDRINI et al., 2010). In the present study, when the tooth surfaces were contaminated, and no decontamination was performed the bond strength values fell significantly when compared with the Control Group that presented a mean of $4.78 \mathrm{MPa}$. This bond strength value is lower than the clinically accepted one, which is in agreement with previous investigations (OONSOMBAT et al., 2003; CACCIAFESTA et al., 2004b; SFONDRINI et al., 2004; SFONDRINI et al., 2010). This demonstrates the need for decontaminating the enamel surface before bonding when the material of choice is Transbond XT, since this material has no affinity for humidity.

In the result obtained in study which Transbond XP was used after contaminating the enamel surface with saliva, the bond strength value was $3.42 \mathrm{MPa}$ and when the enamel was contaminated with blood it was $2.37 \mathrm{MPa}$ (SAYINSU et al., 2007). This study affirms the loss of shear bond strength when the enamel surface is contaminated. The bond strength found in a study on dry surfaces was $26.5 \mathrm{MPa}$ differing from the findings (15.28) of other authors (OZTOPRAK et al., 2007), using the same adhesive material. Whereas, the results of the groups in which the enamel was contaminated with blood the results were close to this value (3.08).

Study demonstrated that the bond strength to enamel contaminated with water or human blood presented mean bond strength higher than values found in this study, being $12.89 \mathrm{MPa}$ and 11.16 $\mathrm{MPa}$ respectively (HOBSON et al., 2001). The variability in the results may be attributed to the use of a different primer, Transbond MIP, which has hydrophilic characteristics.

The explanation for the reduction in shear bond strength lies in the chemical composition of blood, which interferes in the links between the resin and adhesive, forming a physical barrier that prevents tag formation, leading to a reduction in mechanical retention (SFONDRINI et al., 2004; BRAUCHLI et al., 2010). Moreover, saliva is composed mainly of water (99\%), polysaccharides, proteins, and enzymes. The mechanism of contamination occurs by forming an organic smear layer, covering the porous surface. In addition to the loss of mechanical adherence, the chemical bond between the calcium and phosphate ions has also been related (SFONDRINI et al., 2004).

One observes that various studies have analyzed shear bond strength in a dry, contaminated environment; nevertheless, there is a scarcity of studies that evaluate the influence of decontamination methods on bond strength.

Certainly the complete repetition of all the bonding steps would be the best way to obtain a better bond after enamel has been contaminated. Nevertheless, repeating etching may cause even more enamel loss (BRAUCHLI et al., 2010). Therefore, when a decontamination procedure is performed it will minimize the possibility of a loss of adhesiveness occurring (SFONDRINI et al., 2004; BRAUCHLI et al., 2010).

The mean bond strength values found in study that used the composite Eagle Blond and there was contamination with blood and saliva, was 6.89 $\mathrm{MPa}$, and after performing washing and drying it was $10.25 \mathrm{MPa}$. For the groups using the composite Orthoprimer contaminated with blood and saliva it was 7.28 MPa and after washing and drying it was $8.73 \mathrm{MPa}$ (PITHON et al., 2007). The present study showed higher values when different methods of washing and drying were used, however, one must consider the use of different composites in the methodology. This emphasizes that the methods of decontamination may increase adhesiveness and avoids having to re-etch the enamel.

In the present study, when the decontamination method was washing only, using distilled water or physiologic serum without drying (Group DW and PS), the bond strength values found were low 9.41 e 8.91 respectively. The values were statistically lower than those of the Control Group.

In the decontamination methods in which only drying with air was performed (Group JA), after contamination a lower result was obtained in comparison with only drying with gauze or cotton wool (Group $\mathrm{G}$ and $\mathrm{CW}$ ), showing statistical difference between them, and also between the three groups and the Control Group.

Washing with physiologic solution and drying with a jet of air (Group PS+JA with mean = $27.43 \mathrm{MPa}$ ), and also washing with distilled water and drying with a jet of air (Group DW+JA with mean $=24.80 \mathrm{MPa}$ ) provided bond strengths close to those of bonding buttons of the Control Group who were not contamination or decontamination procedures performed. Once the Groups DW+JA and PS+JA demonstrated absence of statistical differences when compared with the Control Group $(P>0.05)$. Thus, these decontamination procedures were shown to be clinically acceptable. The reason for these results may be related to the fact that the pressure exerted by Jets of air was able of satisfactorily remove the substances used to wash the contamination of blood / saliva compared eg. manual cleaning with gauze or cotton. 
In another study the mean bond strength of 25.06 MPa was found in the Control Group. In the group contaminated with blood the mean was 4.88 and in the group contaminated with blood and decontaminated using water a mean of $21.37 \mathrm{MPa}$ was obtained (BRAUCHLI et al., 2010). These results corroborate the findings of the present study.

The groups that were submitted to decontamination processes presented bond strength values that were higher than the minimum for orthodontic accessories bonded to enamel (REYNOLDS, 1975), because according to this author a bond strength of 6-8 MPa is adequate for the majority of orthodontic clinical requirements to bear the forces of mastication and orthodontic mechanics (CACCIAFESTA et al., 2004ab; SFONDRINI et al., 2004; OZTOPRAK et al., 2007; GAMA et al., 2013). However, among the methods of decontamination, the groups that were submitted to washing only, presented lower mean values.

\section{CONCLUSION}

The best method of decontamination for enamel contaminated with blood/saliva after etching is washing with distilled water or physiologic solution followed by drying with jets of air.

RESUMO: O presente estudo teve como objetivo avaliar o melhor método para descontaminação do esmalte dental contaminado com sangue/saliva antes da colagem de acessórios ortodônticos, uma vez que tal contaminação é comumente presente em procedimentos cirúrgicos de extrusão/ortodontia. Foram utilizados 195 incisivos bovinos. Inicialmente, suas faces vestibulares receberam profilaxia, H3PO4 a 37\% e aplicação de adesivo. Em seguida, as faces vestibulares de todos os dentes foram contaminadas com sangue/saliva. Os dentes foram então divididos aleatoriamente em 13 grupos $(\mathrm{n}=15)$, Grupo $\mathrm{C}$ (Controle - sem contaminação e colados de acordo com as recomendações do fabricante) e 12 grupos experimentais de acordo com o método de descontaminação: Grupo WD - sem descontaminação, Grupo DW lavados com água destilada, Grupo PS - lavadas com solução fisiológica, Grupo JA - jatos de ar, Grupo G - gaze, Grupo CW - algodão, Grupo DW+JA - água destilada + jatos de ar, Grupo DW+G - água destilada + gaze, Grupo DW+CW água destilada + algodão, Grupo PS+JA - solução fisiológica + jatos de ar, Grupo PS+G - solução fisiológica + gaze, Grupo PS+CW - solução fisiológica + algodão. Após a colagem o ensaio de resistência ao cisalhamento foi realizado em todas as amostras a uma velocidade de $0,5 \mathrm{~mm} / \mathrm{min}$. Os dados foram analisados estatisticamente por ANOVA e teste de Tukey com nível de significância de 5\%. Os resultados mostraram ausência de diferenças estatísticas entre os grupos controle e Grupos DW+JA e PS+JA $(P>0,05)$. Os grupos que apresentaram os menores valores de resistência de união foram Grupo WD, em que nenhuma descontaminação foi executada, e Grupo PS em que as amostras foram lavadas apenas com solução fisiológica. Os melhores métodos de descontaminação esmalte contaminado com sangue/saliva foram lavados com água destilada ou solução fisiológica seguidos por secagem com jatos de ar.

PALAVRAS-CHAVE: Materiais Dentários. Ortodontia. Procedimentos Cirúrgicos Bucais. Resistência ao cisalhamento.

\section{REFERENCES}

BRAUCHLI, L.; EICHENBERGER, M.; STEINECK, M.; WICHELHAUS, A. Influence of decontamination procedures on shear forces after contamination with blood or saliva. Am. J. Orthod. Dentofacial Orthop. St. Louis, v. 138, n. 4, p. 435-441, Oct. 2010. http://dx.doi.org/10.1016/j.ajodo.2008.10.021

CACCIAFESTA, V.; SFONDRINI, M. F.; DE ANGELIS, M.; SCRIBANTE, A.; KLERSY, C. Effect of water and saliva contamination on shear bond strength of brackets bonded with conventional, hydrophilic, and selfetching primers. Am. J. Orthod. Dentofacial Orthop. St. Louis, v. 123, n. 6, p. 633-640, Jun. 2003. http://dx.doi.org/10.1016/S0889-5406(03)00198-7

CACCIAFESTA, V.; SFONDRINI, M. F.; SCRIBANTE, A.; DE ANGELIS, M.; KLERSY, C. Effects of blood contamination on the shear bond strengths of conventional and hydrophilic primers. Am. J. Orthod. Dentofacial Orthop. St. Louis, v. 126, n. 2, p. 207-212, Aug. 2004a. http://dx.doi.org/10.1016/j.ajodo.2003.06.022 
CACCIAFESTA, V.; SFONDRINI, M. F.; SCRIBANTE, A.; DE ANGELIS, M.; KLERSY, C. Effect of blood contamination on shear bond strength of brackets bonded with a self-etching primer combined with a resinmodified glass ionomer. Am. J. Orthod. Dentofacial Orthop. St. Louis, v. 126, n. 6, p. 703-708, Dec. 2004 b. http://dx.doi.org/10.1016/j.ajodo.2003.10.041

CAMPOY, M. D.; PLASENCIA, E.; VICENTE, A.; BRAVO, L. A.; CIBRIAN, R. Effect of saliva contamination on bracket failure with a self-etching primer: a prospective controlled clinical trial. Am. J. Orthod. Dentofacial Orthop. St. Louis, v. 137, n. 5, p. 679-683, May. 2010.

FERREIRA-JUNIOR, O.; DE AVILA, L. D.; SAMPIERI, M. B.; DIAS-RIBEIRO, E.; CHEN, W. L.; FAN, S. Impacted lower third molar fused with a supernumerary tooth--diagnosis and treatment planning using conebeam computed tomography. Int. J. Oral Sci. Sichuan, v. 1, n. 4, p. 224-228, Dec. 2009. http://dx.doi.org/10.4248/IJOS09056

GAMA, A. C. S.; MORAES, A. G. V.; YAMASAKI, L. C.; LOGUERCIO, A. D.; CARVALHO, C. N.; BAUER, J. Properties of Composite Materials Used for Bracket Bonding. Braz. Dent. J. Ribeirão Preto, v. 24, n. 3, p. 279-283, Jun. 2013.

HOBSON, R. S.; LEDVINKA, J.; MEECHAN, J. G. The effect of moisture and blood contamination on bond strength of a new orthodontic bonding material. Am. J. Orthod. Dentofacial Orthop. St. Louis, v. 120, n. 1, p. 54-57, Jul. 2001. http://dx.doi.org/10.1067/mod.2001.115037

KOKICH, V. G. Surgical and orthodontic management of impacted maxillary canines. Am. J. Orthod. Dentofacial Orthop. St. Louis, v. 126, n. 4, p. 278-283, Sep. 2004. http://dx.doi.org/10.1016/j.ajodo.2004.06.009

KOKICH, V. G.; CRABILL, K. E. Managing the patient with missing or malformed maxillary central incisors. Am. J. Orthod. Dentofacial Orthop. St. Louis, v. 129, n. 4, p. 55-63, Apr. 2006. http://dx.doi.org/10.1016/j.ajodo.2005.11.007

KOKICH, V.G.; MATHEWS, D. P. Surgical and orthodontic management of impacted teeth. Dent. Clin. North Am. Philadelphia, v. 37, n. 2, p. 181-204, Apr. 1993.

MAIA, S. R.; CAVALLI, V.; LIPORONI, P. C.; REGO, M. A. Influence of saliva contamination on the shear bond strength of orthodontic brackets bonded with self-etching adhesive systems. Am. J. Orthod. Dentofacial Orthop. St. Louis, v. 138, n. 1, p. 79-83, Jul. 2010. http://dx.doi.org/10.1016/j.ajodo.2008.08.035

OONSOMBAT, C.; BISHARA, S. E.; AJLOUNI, R. The effect of blood contamination on the shear bond strength of orthodontic brackets with the use of a new self-etch primer. Am. J. Orthod. Dentofacial Orthop. St. Louis, v. 123, n. 5, p. 547-550, May. 2003.

OZTOPRAK, M. O.; ISIK, F.; SAYINSU, K.; ARUN, T.; AYDEMIR, B. Effect of blood and saliva contamination on shear bond strength of brackets bonded with 4 adhesives. Am. J. Orthod. Dentofacial Orthop. St. Louis, v. 131, n. 2, p. 238-242, Feb. 2007. http://dx.doi.org/10.1016/j.ajodo.2005.02.035

PITHON, M. M.; DE OLIVEIRA, M. V.; SANT’ANNA, E. F.; ARAÚJO, M. T.; RUELlAS, A. C. O. Influence of the contamination of blood mixed with saliva on adhesive shear resistance and the indices of adhesive remaining the two new composites. Saúde.com. Jéquie, v. 3, n. 2, p. 37-44, May. 2007. http://dx.doi.org/10.1093/ejo/cjp160

PITHON, M. M.; DOS SANTOS, R. L.; RUELLAS, A. C.; SANT'ANNA, E. F. One-component self-etching primer: a seventh generation of orthodontic bonding system? Eur. J. Orthod. Oxford, v. 32, n. 5, p. 567-570, Oct. 2010. 
REYNOLDS, I. R. A review of direct orthodontic bonding. Br. J. Orthod. Craniofac. Res. Oxford, v. 2, n. 1, p. 171-178, Jan. 1975.

SAYINSU, K.; ISIK, F.; SEZEN, S.; AYDEMIR, B. Effect of blood and saliva contamination on bond strength of brackets bonded with a protective liquid polish and a light-cured adhesive. Am. J. Orthod. Dentofacial Orthop. St. Louis, v. 131, n. 3, p. 391-394, Mar. 2007. http://dx.doi.org/10.1016/j.ajodo.2005.04.049

SFONDRINI, M. F.; CACCIAFESTA, V.; SCRIBANTE, A.; DE ANGELIS, M.; KLERSY, C. Effect of blood contamination on shear bond strength of brackets bonded with conventional and self-etching primers. Am. J. Orthod. Dentofacial Orthop. St. Louis, v. 125, n. 3, p. 357-360, Mar. 2004. http://dx.doi.org/10.1016/j.ajodo.2003.09.022

SFONDRINI, M. F.; GATTI, S.; SCRIBANTE, A. Effect of blood contamination on shear bond strength of orthodontic brackets and disinclusion buttons. Br. J. Oral Maxillofac. Surg. Oxford, v. 49, n. 5, p. 404-408, Jul. 2010. http://dx.doi.org/10.1016/j.bjoms.2010.06.011

YANG, W. S. An orthodontic case of impacted tooth treated by direct bonding system. Taehan Chi. Uisa Hyophoe Chi. Seoul, v. 11, n. 3, p. 171-175, Mar. 1973. 